\title{
Polarographic Studies on Complex Formation of Cryptand[2.2] and a Macrocyclic Polythioetheramine with Alkali or Alkaline-Earth Metal Ions in Acetonitrile
}

\author{
Masashi HoJo*, Hiroshi HaSegawa*, Takanori OHNo*, \\ Souichirou ArISAWA* and Kenji Chayama** \\ * Department of Chemistry, Faculty of Science, Kochi University, \\ Akebono-cho, Kochi 780, Japan \\ **Department of Chemistry, Faculty of Science, Konan University, \\ Okamoto, Higashinada, Kobe 658, Japan
}

\begin{abstract}
The formation constants for $1: 1$ complexes between $\mathrm{Li}^{+}$or $\mathrm{Na}^{+}$and a monocyclic polyetherdiamine, cryptand[2.2], were evaluated in acetonitrile at $25 \pm 0.2^{\circ} \mathrm{C}$ by three d.c. polarographic analyses: the positive shift in $E_{1 / 2}$ of the anodic (mercury dissolution) wave induced from cryptand[2.2] in the presence of a large excess of $\mathrm{LiClO}_{4}$ and $\mathrm{NaClO}_{4}$; the positive shift in $E_{1 / 2}$ of the cathodic wave of the [HgL] $]^{2+}$ complex ( $\mathrm{L}=$ cryptand[2.2]) in the presence of a large excess of alkali metal ions; and the negative shift of the cathodic wave of $\mathrm{Li}^{+}$or $\mathrm{Na}^{+}$in the presence of a large excess of cryptand[2.2]. The above three analyses gave complex formation constants that were consistent with each other within experimental error. In a less solvating medium (benzonitrile), stronger interactions were observed between the cations and cryptand[2.2]. The interaction between alkali metal ions and 1,10-diaza-4,7,13,16-tetrathiacyclooctadecane (ATCO) was very small, even in benzonitrile. The complex formation constants of $[\mathrm{SrL}]^{2+}$ and $[\mathrm{BaL}]^{2+}\left(\mathrm{L}^{\prime}=\mathrm{ATCO}\right)$ in acetonitrile were both $c a .10^{2.5}$ by the first two methods mentioned above.
\end{abstract}

Keywords Cryptand[2.2], macrocyclic polythioetheramine, polarography, anodic wave, acetonitrile, complex formation

We have found the formation of new species, $\mathrm{RCOO}^{-}$ $\left(\mathrm{M}^{+}\right)_{2}\left(\mathrm{R}=\mathrm{CH}_{3}\right.$ and $\mathrm{C}_{6} \mathrm{H}_{5} ; \mathrm{M}^{+}=\mathrm{Li}^{+}$and $\left.\mathrm{Na}^{+}\right)$, in acetonitrile by means of a newly developed polarographic analysis. ${ }^{1}$ Complex ions, $\mathrm{M}^{+}\left(\mathrm{C}_{6} \mathrm{H}_{5} \mathrm{COO}^{-}\right)_{2}\left(\mathrm{M}^{+}=\mathrm{Li}^{+}\right.$, $\mathrm{Na}^{+}$and $\mathrm{K}^{+}$), were also observed ${ }^{1}$ by the usual polarographic analysis. The presence of such "extraordinary" species has been convinced by further investigations with spectrophotometry ${ }^{2}$ and conductometry. ${ }^{3}$

In previous papers, we have reported on the complex formation of $\mathrm{Li}^{+}$and $\mathrm{Na}^{+}$with acyclic polyamines ${ }^{4}$ as well as cyclic polyamines (cyclam and tetramethylcyclam) 5,6 by utilizing the anodic waves of amines. Although one of the crown ethers, 18-crown-6, was found to give a welldefined anodic wave, the $E_{1 / 2}$ was too close to the positive potential limit to evaluate the interaction between $\mathbf{M}^{+}$ and the crown ether. ${ }^{6}$ Introduction of nitrogen atoms into a crown ether may provide sufficient coordination ability towards $\mathrm{Hg}^{2+}$.

Interactions of cryptand[2.2] with ions ${ }^{7}$ and neutral molecules ${ }^{8}$ have been extensively investigated and been reviewed by Izatt et al. Very recently, the complexation of alkali metal ions with crown ethers and cryptands in acetone was examined based on potentiometric and calorimetric titrations. ${ }^{9}$ Effective solvent extractions of "soft" metals with cyclic polythioethers (including monoaza- and diaza-derivatives) have been reported by Chayama et al..$^{10,11}$

In the present study, a monocyclic polyetherdiamine, (cryptand[2.2]) and its sulfur derivative (ATCO) were examined by polarography in acetonitrile. It is predicted that the small affinity of sulfur atoms towards alkali metal ions may cause a weak interaction between ATCO and alkali metal ions.<smiles>C1COCCOCCOCCOCCOCCN1</smiles><smiles>N#CCCSCCNCCSCCSCCNCCSCC(=O)Cl</smiles>

\section{Experimental}

(Cryptand[2.2]) 1,4,10,13-tetraoxa-7,16-diazacyclooctadecane from Aldrich was used as received. 1,10Diaza-4,7,13,16-tetrathiacyclooctadecane (ATCO) was prepared by the method of Dietrich et al. ${ }^{12}$ Acetonitrile and benzonitrile (both Wako, GR grade) were used without further purification. Anhydrous lithium per- 
chlorate (Wako, GR grade) was used as received. Anhydrous sodium perchlorate was prepared from $\mathrm{NaClO}_{4} \cdot \mathrm{H}_{2} \mathrm{O}$ (Wako, EP grade), and was dried in vacuo at $180^{\circ} \mathrm{C}$ over $\mathrm{P}_{2} \mathrm{O}_{5}$. Tributylammonium perchlorate $\left(\mathrm{Bu}_{3} \mathrm{NHClO}_{4}\right)$ was prepared from tributylamine and $\mathrm{HClO}_{4}$. The crystals were dried in vacuo at $60^{\circ} \mathrm{C}$. $\mathrm{Mg}\left(\mathrm{ClO}_{4}\right)_{2}$ and $\mathrm{Ba}\left(\mathrm{ClO}_{4}\right)_{2}$ (both Wako, GR grade) were dried in vacuo at $200^{\circ} \mathrm{C}$ and $180^{\circ} \mathrm{C}$, respectively. $\mathrm{Ca}\left(\mathrm{ClO}_{4}\right)_{2}$ and $\mathrm{Sr}\left(\mathrm{ClO}_{4}\right)_{2}$ were prepared from $\mathrm{Ca}(\mathrm{OH})_{2}$ and $\mathrm{SrCO}_{3}$ with $\mathrm{HClO}_{4}$, respectively, and were dried in vacuo at $200^{\circ} \mathrm{C}$. $\mathrm{Hg}\left(\mathrm{ClO}_{4}\right)_{2} \cdot 3 \mathrm{H}_{2} \mathrm{O}$ (Wako, EP grade) was used as received. A solution of $0.1 \mathrm{~mol} \mathrm{dm}^{-3}$ $\mathrm{HClO}_{4}-\mathrm{MeCN}$ was prepared by diluting $\mathrm{HClO}_{4}$ (Wako, GR grade, $60 \%$ ) with acetonitrile. The minor effects of water from $\mathrm{Hg}\left(\mathrm{ClO}_{4}\right) \cdot 3 \mathrm{H}_{2} \mathrm{O}$ and $60 \% \mathrm{HClO}_{4}$ were ignored. Other chemicals were used as mentioned previously..$^{4-6}$

Direct-current polarograms were recorded by a Yanagimoto polarograph (Model P-1000) and a Graphtec X-Y recorder (Model WX-4410-L0). The rate of the potential sweep was $5 \mathrm{mV} / \mathrm{s}$. The dropping mercury electrode had the following open-circuit characteristics: $m=2.56 \mathrm{mg} / \mathrm{s}$ and $\tau=5.14 \mathrm{~s}$ in a $0.1 \mathrm{~mol} \mathrm{dm}^{-3}$ $\mathrm{Et}_{4} \mathrm{NClO}_{4}-\mathrm{MeCN}$ solution at $h=50 \mathrm{~cm}$. The drop time was regulated to be $1.0 \mathrm{~s}$ by means of a Yanagimoto ( $P$ 1000-ST) drop-timer. The reference electrode was an $\mathrm{Ag} / 0.1 \mathrm{~mol} \mathrm{dm}^{-3} \mathrm{AgClO}_{4}-\mathrm{MeCN}$ electrode. All of the polarographic measurements were carried out at $25 \pm 0.2^{\circ} \mathrm{C}$.

\section{Results and Discussion}

\section{Anodic wave of cryptand[2.2] and cathodic wave of the} mercury complex

An anodic (mercury dissolution) wave was produced at $-0.29 \mathrm{~V}$ by $0.3 \mathrm{mmol} \mathrm{dm}^{-3}$ cryptand[2.2] in acetonitrile containing $0.1 \mathrm{~mol} \mathrm{dm}^{-3} \mathrm{Et}_{4} \mathrm{NClO}_{4}$ as the supporting electrolyte $\left(c f . E_{1 / 2}=-0.41\right.$ and $+0.22 \mathrm{~V}$ for tetramethylcycram and 18-crown-6, respectively). ${ }^{6}$ A wave analysis [E vs. $\left.\log \left\{i /\left(i_{\mathrm{d}}-i\right)\right\}, 36 \mathrm{mV}\right]$ suggested a reversible 2electron process. The alternation of the supporting electrolyte to $\mathrm{Bu}_{4} \mathrm{NClO}_{4}$ gave no change in the wave. When using $\mathrm{Na}^{+}, \mathrm{Li}^{+}$or $\mathrm{Bu}_{3} \mathrm{NH}^{+}$, however, the anodic wave was shifted positively (Fig. 1). The half-wave potential $\left(E_{1 / 2}\right)$ and current values are listed in Table 1. The waves were all diffusion controlled $\left(i_{1} \propto \sqrt{h}\right)$. It should be mentioned that it has been reported that a bicyclic polyetherdiamine, cryptand[2.2.2] ${ }^{13}$, gives an anodic wave at $-0.29 \mathrm{~V}$ vs. $\mathrm{Ag} / 0.1 \mathrm{~mol} \mathrm{dm}^{-3} \mathrm{AgClO}_{4}$ $\mathrm{MeCN}$. However, by the addition of $0.1 \mathrm{~mol} \mathrm{dm}^{-3}$ $\mathrm{LiClO}_{4}$ or $\mathrm{NaClO}_{4}$ to $0.2 \mathrm{mmol} \mathrm{dm}{ }^{-3}$ cryptand[2.2.2], the (anodic) wave was deformed and its height was much decreased, although the $E_{1 / 2}$ was shifted positively. The polarographic irreversibility (slow reaction) in the complexation between cryptand[2.2.2] and the alkali metal ions prevented us from obtaining formation constants by means of polarography.

Amperometric titration was performed for 0.5

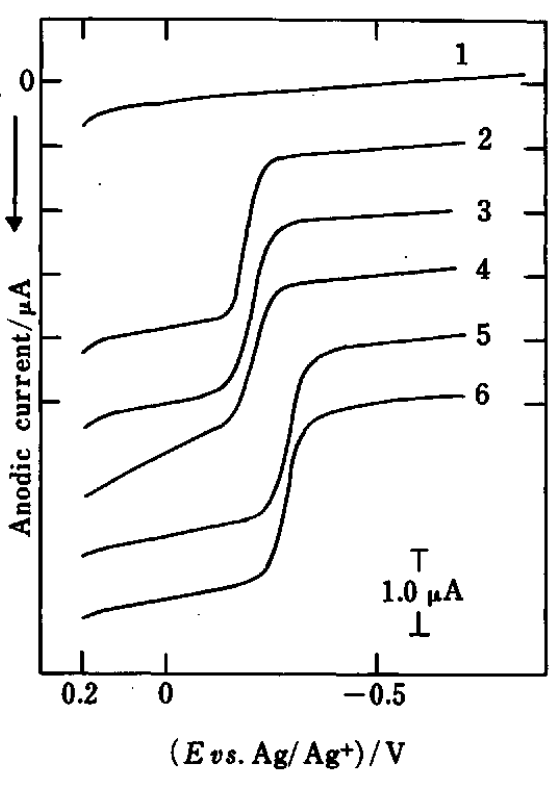

Fig. 1 D.c. polarograms of $0.30 \mathrm{mmol} \mathrm{dm}^{-3}$ cryptand[2.2] in acetonitrile containing various supporting electrolytes (all $0.1 \mathrm{~mol} \mathrm{dm}^{-3}$ ). (1) Base current of $\mathrm{Et}_{4} \mathrm{NClO}_{4}$, (2) $\mathrm{NaClO}_{4}$, (3) $\mathrm{LiClO}_{4}$, (4) $\mathrm{Bu}_{3} \mathrm{NHClO}_{4}$, (5) $\mathrm{Et}_{4} \mathrm{NClO}_{4}$, (6) $\mathrm{Bu}_{4} \mathrm{NClO}_{4}$

Table 1 D.c. polarographic data for anodic waves of cryptand[2.2] and ATCO in acetonitrile containing various supporting electrolytes at $25^{\circ} \mathrm{C}$

\begin{tabular}{ccc}
\hline Supporting electrolyte & $E_{1 / 2} \mathrm{~b} / \mathrm{V}$ & $i_{1} / \mu \mathrm{A}$ \\
\hline [Cryptand[2.2]] $=0.30 \mathrm{mmol} \mathrm{dm}^{-3}$ & & \\
$\mathrm{Et}_{4} \mathrm{NClO}_{4}$ & -0.29 & 1.9 \\
$\mathrm{Bu}_{4} \mathrm{NClO}_{4}$ & -0.29 & 1.9 \\
$\mathrm{NaClO}_{4}$ & -0.19 & 1.8 \\
$\mathrm{LiClO}_{4}$ & -0.20 & 1.9 \\
$\mathrm{Bu}_{3} \mathrm{NHClO}_{4}$ & -0.21 & 1.5 \\
{$[\mathrm{ATCO}]=0.30 \mathrm{mmol} \mathrm{dm}^{-3}$} & & \\
$\mathrm{Et}_{4} \mathrm{NClO}_{4}$ & -0.42 & 1.9 \\
$\mathrm{Bu}_{4} \mathrm{NClO}_{4}$ & -0.41 & 1.9 \\
$\mathrm{NaClO}_{4}$ & -0.41 & 1.9 \\
$\mathrm{LiClO}_{4}$ & -0.41 & 1.7 \\
$\mathrm{Bu}_{3} \mathrm{NHClO}_{4}$ & -0.38 & 1.5 \\
${\mathrm{Mg}\left(\mathrm{ClO}_{4}\right)_{2}}_{\mathrm{Ca}\left(\mathrm{ClO}_{4}\right)_{2}}$ & $-{ }^{\mathrm{c}}$ & - \\
$\mathrm{Sr}\left(\mathrm{ClO}_{4}\right)_{2}$ & -0.20 & $(0.3)$ \\
$\mathrm{Ba}\left(\mathrm{ClO}_{4}\right)_{2}$ & -0.38 & 1.0 \\
\hline
\end{tabular}

a. Concentrations of the supporting electrolytes are $0.1 \mathrm{~mol}$ $\mathrm{dm}^{-3}$, except for alkaline-earth metal salts $\left(0.05 \mathrm{~mol} \mathrm{dm}^{-3}\right)$. b. vs. $\mathrm{Ag} / 0.1 \mathrm{~mol} \mathrm{dm}^{-3} \mathrm{AgClO}_{4}-\mathrm{MeCN}$ electrode.

c. The anodic wave disappeared completely.

mmol dm${ }^{-3}(10 \mathrm{ml})$ cryptand[2.2] with $0.1 \mathrm{~mol} \mathrm{dm}^{-3}$ $\mathrm{Hg}\left(\mathrm{ClO}_{4}\right)_{2}$ in acetonitrile (Fig. 2). Upon the addition of a small amount of $\mathrm{Hg}^{2+}$, some portion of the anodic wave changed to the cathodic portion. The wave changed entirely to the cathodic portion at the equivalent point ([L]: $\left[\mathrm{Hg}^{2+}\right]=1: 1$ where $\mathrm{L}=$ cryptand[2.2], cf. Eq. (1)). No shift in $E_{1 / 2}$ was observed, although the wave height of 


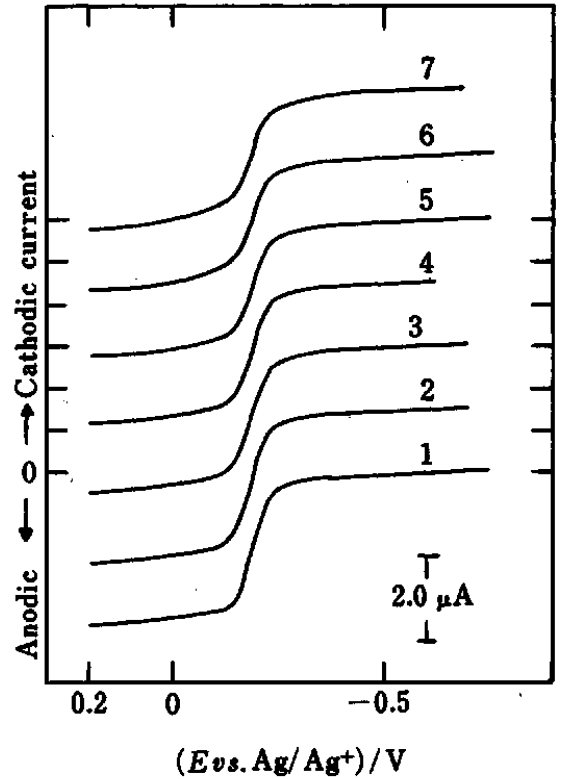

Fig. 2 Changes in current position in polarograms of 0.50 mmol dm${ }^{-3}$ cryptand [2.2] in acetonitrile with the addition of $\mathrm{Hg}\left(\mathrm{ClO}_{4}\right)_{2}$. (1) 0 , (2) 0.1 , (3) 0.2 , (4) 0.3 , (5) 0.4 , (6) 0.5 , (7) $0.6 \mathrm{mmol} \mathrm{dm}^{-3}$ of $\mathrm{Hg}^{2+}$. The supporting electrolyte was $0.1 \mathrm{~mol} \mathrm{dm}^{-3} \mathrm{Et}_{4} \mathrm{NClO}_{4}$.

the cathodic wave was slightly smaller than that of the initial anodic wave. Unreacted $\mathrm{Hg}^{2+}$ was found after the equivalent point. The above results suggested that the combination of $\mathrm{Hg}^{2+}$ and $\mathrm{L}$ gave the $\mathrm{HgL}^{2+}$ species in the solution, which could be reduced by 2 -electrons to $\mathrm{Hg}$ and $\mathrm{L}$ :

$$
\mathrm{Hg}^{2+}+\mathrm{L} \rightleftarrows[\mathrm{HgL}]^{2+}
$$

and

$$
[\mathrm{HgL}]^{2+}+2 \mathrm{e}^{-} \rightleftarrows \mathrm{Hg}+\mathrm{L} \text {. }
$$

Figure 3 shows the shift in $E_{1 / 2}$ of the anodic wave of cryptand[2.2] with increasing concentration of (Lewis) acids. When $10-200 \mathrm{mmol} \mathrm{dm}^{-3} \mathrm{LiClO}_{4}$ was added to $0.3 \mathrm{mmol} \mathrm{dm}^{-3}$ cryptand[2.2], the $E_{1 / 2}$ of the anodic wave shifted by $29 \mathrm{mV}$ positively due to the increase of a 10 fold $\mathrm{Li}^{+}$concentration. The magnitude of the shift in $E_{1 / 2}\left(\Delta E_{1 / 2} / \Delta \log \left[\mathrm{Li}^{+}\right]=29 \mathrm{mV}\right)$ indicated the formation of the $[\mathrm{LiL}]^{+}$complex with a formation constant of $10^{3.9}$. Similar $E_{1 / 2}$ shifts were observed for the cathodic wave of $\mathrm{HgL}^{2+}$ in the presence of a large excess of $\mathrm{Li}^{+}$. The formation constant of the $[\mathrm{LiL}]^{+}$complex was obtained to be $10^{3.8}$ by the cathodic wave of $\mathrm{HgL}^{2+}$. Equation (3) was utilized for evaluating the complex formation constants by the anodic wave of $\mathrm{L}$ (or the cathodic wave of $\left.[\mathrm{HgL}]^{2+}\right)$ :

$$
\begin{aligned}
\left(E_{1 / 2}\right)_{\mathrm{o}}= & \left(E_{1 / 2}\right)_{\mathrm{s}}+(0.059 / 2) \log K_{p} \\
& +(0.059 / 2) p \log \left[\mathrm{M}^{+}\right],
\end{aligned}
$$

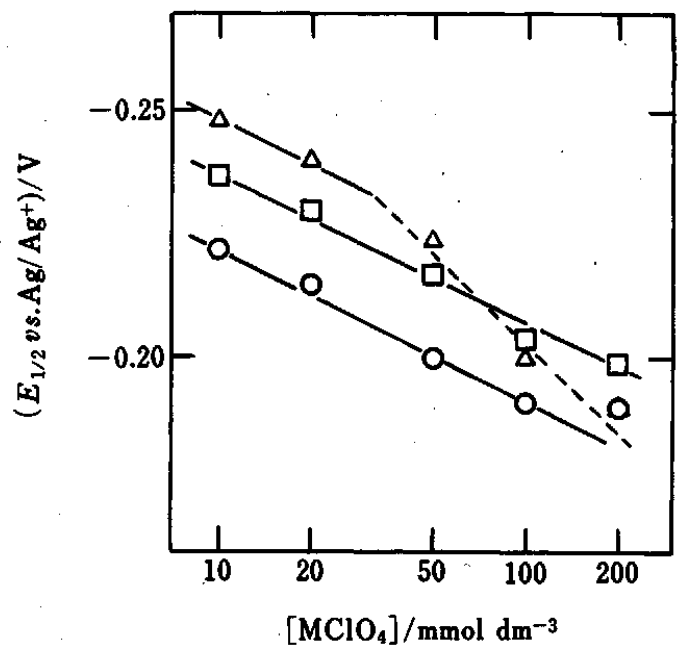

Fig. 3 Shift in $E_{1 / 2}$ of the anodic wave of $0.30 \mathrm{mmol} \mathrm{dm}^{-3}$ cryptand [2.2] in acetonitrile with increasing concentration of (Lewis) acids. (O) $\mathrm{NaClO}_{4},(\square) \mathrm{LiClO}_{4},(\triangle) \mathrm{Bu}_{3} \mathrm{NHClO}_{4}$. The ionic strength was kept to be 0.1 by $\mathrm{Et}_{4} \mathrm{NClO}_{4}$, except for $0.2 \mathrm{~mol} \mathrm{dm}^{-3} \mathrm{MClO}_{4}$.

\begin{tabular}{|c|c|c|c|}
\hline \multirow{2}{*}{ Cation } & \multicolumn{2}{|c|}{ Anodic wave } & \multirow{2}{*}{$\frac{\mathrm{M}^{+} \text {reduction wave }}{\log K_{1}}$} \\
\hline & $\log K_{1}$ & $\log K_{2}$ & \\
\hline $\mathrm{Li}^{+}$ & $\begin{array}{l}3.9 \\
3.8^{\mathrm{a}}\end{array}$ & & 4.1 \\
\hline $\mathrm{Na}^{+}$ & $\begin{array}{l}4.4 \\
4.3^{\mathrm{a}}\end{array}$ & & 4.3 \\
\hline $\mathbf{K}^{+}$ & - & & 4.4 \\
\hline $\mathrm{Bu}_{3} \mathrm{NH}^{+}$ & $\begin{array}{l}3.6 \\
3.6^{a}\end{array}$ & $\begin{array}{l}5.1 \\
5.1^{\mathrm{a}}\end{array}$ & \\
\hline
\end{tabular}

Table 2 Formation constants $\left(\log K_{p}\right)$ between cations and crystand[2.2] in acetonitrile, obtained by the three methods at $25^{\circ} \mathrm{C}$

a. The value by the cathodic wave of $[\mathrm{HgL}]^{2+}$.

where $\left(E_{1 / 2}\right)_{0}$ is the $E_{1 / 2}$ of the anodic wave of $\mathrm{L}$ (or the cathodic wave of $[\mathrm{HgL}]^{2+}$ ) in the presence of $\mathrm{M}^{+}$, and $\left(E_{1 / 2}\right)_{\mathrm{s}}$ is that in the absence of $\mathrm{M}^{+} ; K_{p}$ is the (overall) formation constant, and $p$ is the number of $\mathrm{M}^{+}$to combine with $\mathrm{L}$.

Sodium ions had effects similar to those of $\mathrm{Li}^{+}$. The formation constants for $\mathrm{Na}^{+}$were obtained both by the anodic $(\mathrm{L})$ and cathodic $\left(\mathrm{HgL}^{2+}\right)$ in the presence of a large excess of $\mathrm{Na}^{+}$, and are listed in Table 2 . The solubility of potassium perchlorate in acetonitrile was too small to be a large excess over the concentration of cryptand[2.2].

In benzonitrile, $0.7 \mathrm{mmol} \mathrm{dm}^{-3}$ cryptand [2.2] gave an anodic wave at $-0.37 \mathrm{~V}$ vs. $\mathrm{Ag} / 0.1 \mathrm{~mol} \mathrm{dm}^{-3}-\mathrm{Ag}^{+} \mathrm{PhCN}$ (the reference electrode). The addition of $\mathrm{LiClO}_{4}$ or $\mathrm{NaClO}_{4}$ caused the $E_{1 / 2}$ to shift positively. The formation constants of $[\mathrm{ML}]^{+}$were calculated to be $10^{6.3}$ and $10^{6.5}$ for $\mathrm{Li}^{+}(5-200 \mathrm{mmol} \mathrm{dm}-3, p=1.36)$ and $\mathrm{Na}^{+}(5-$ $50 \mathrm{~mol} \mathrm{dm}^{-3}, \quad p=1.0$ ), respectively. The very large formation constants of $\mathrm{Li}^{+}$and $\mathrm{Na}^{+}$in benzonitrile, 
compared with those in acetonitrile, can be explained by the smaller solvation ability of $\mathrm{PhCN}$ (DN=11.9, $\mathrm{AN}=15.5)$ than that of $\mathrm{MeCN}(\mathrm{DN}=14.1, \mathrm{AN}=19.3) .^{14}$

On the other hand, in the presence of a large excess of $\mathrm{Bu}_{3} \mathrm{NHClO}_{4}$, the $E_{1 / 2}$ of the anodic wave of cryptand[2.2] shifted positively by $30 \mathrm{mV}\left(10-30 \mathrm{mmol} \mathrm{dm}^{-3}\right.$ of $\left.\mathrm{Bu}_{3} \mathrm{NH}^{+}\right)$and $60 \mathrm{mV}\left(30-200 \mathrm{mmol} \mathrm{dm}^{-3}\right)$ in acetonitrile. The (anodic) wave height was not so affected by the presence of weak Bronsted acid ( $c f$. , Fig. 1 or Table 1). Slopes of $30 \mathrm{mV}(p=1)$ and $60 \mathrm{mV}(p=2)$ suggested the formation of $\mathrm{Bu}_{3} \mathrm{NH}^{+} \mathrm{L}\left(\log K_{1}=3.6\right)$ and $\left(\mathrm{Bu}_{3} \mathrm{NH}^{+}\right)_{2} \mathrm{~L} \quad\left(\log K_{2}=5.1\right)$, respectively. Tributylammonium ions may react successively with nitrogen atoms in the cryptand[2.2] molecule. The $\mathrm{p} K_{\mathrm{a}}$ values of the conjugate acid $\left(\mathrm{L}\left(\mathrm{H}^{+}\right)_{2}\right)$ of cryptand[2.2] in aqueous solution have been reported to be 8.94 and $7.81 .^{15}$

However, the basicity in two amines of cryptand[2.2] could not be differentiated by a strong acid, $\mathrm{HClO}_{4}$, in an acetonitrile solution. Figure 4 shows the amperometric titration of $0.5 \mathrm{mmol} \mathrm{dm}^{-3}$ cryptand[2.2] $(10 \mathrm{ml})$ with $0.1 \mathrm{~mol} \mathrm{dm}^{-3} \mathrm{HClO}_{4}$. The anodic wave height decreased linearly with increasing concentration of $\mathrm{HClO}_{4}$, and completely disappeared at the second equivalent point $\left([\mathrm{L}]:\left[\mathrm{HClO}_{4}\right]=1: 2\right)$. A cathodic wave newly appeared at around $-1.95 \mathrm{~V}$ upon the addition of $\mathrm{HClO}_{4}$, which was accompanied by a maximum wave. The wave height of the cathodic wave reached a constant value at the second equivalent point,

$$
\mathrm{L}+2 \mathrm{H}^{+} \rightleftarrows \mathrm{L}\left(\mathrm{H}^{+}\right)_{2} \text {. }
$$

After the second equivalent point, another cathodic wave appeared at around $-1.3 \mathrm{~V}$. This cathodic wave must have been due to the reduction of unreacted $\mathrm{HClO}_{4}{ }^{16}$

Cathodic wave of alkali metal ions in the presence of a large excess of cryptand[2.2]

Lithium perchlorate gave a reversible cathodic wave $(n=1)$ at $-2.3 \mathrm{~V}$ in acetonitrile containing $0.1 \mathrm{~mol} \mathrm{dm}^{-3}$ $\mathrm{Et}_{4} \mathrm{NClO}_{4}$. Upon the addition of $5-50 \mathrm{mmol} \mathrm{dm}^{-3}$ cryptand[2.2], the cathodic wave of $\mathrm{Li}^{+}$shifted negatively $\left(\Delta E_{1 / 2} / \Delta \log [\mathrm{L}]=-62.5 \mathrm{mV}\right)$. The waves were all diffusion controlled $\left(i_{1} \propto \sqrt{h}\right)$. The negative shift of the half-wave potential of the metal ion in the presence of the ligand was analyzed by the usual method:

$$
\left(E_{1 / 2}\right)_{\mathrm{o}}=\left(E_{1 / 2}\right)_{\mathrm{s}}-0.059 \log K_{p}-0.059 p \log [\mathrm{L}],
$$

where $\left(E_{1 / 2}\right)_{\mathrm{o}}$ and $\left(E_{1 / 2}\right)_{\mathrm{s}}$ are the $E_{1 / 2}$ values of the cathodic wave of $\mathrm{M}^{+}$in the presence and absence of $\mathrm{L}$, respectively; $K_{p}$ is the (overall) formation constant, and $p$ is the number of $\mathrm{L}$ to complex with $\mathrm{M}^{+}$. The slope of $-62.5 \mathrm{mV}(p=1)$ indicated the formation of $[\mathrm{LiL}]^{+}$. The formation constant was $10^{4.1}$; this value is almost coincident with that obtained by the anodic wave of $L$ (or the cathodic wave of $\left.[\mathrm{HgL}]^{2+}\right)$. The cathodic waves of $\mathrm{Na}^{+}$and $\mathrm{K}^{+}$were also shifted negatively ( -65 and $-58 \mathrm{mV}$, respectively) by the presence of the ligand. The formation constants of $[\mathrm{NaL}]^{+}$and $[\mathrm{KL}]^{+}$were found

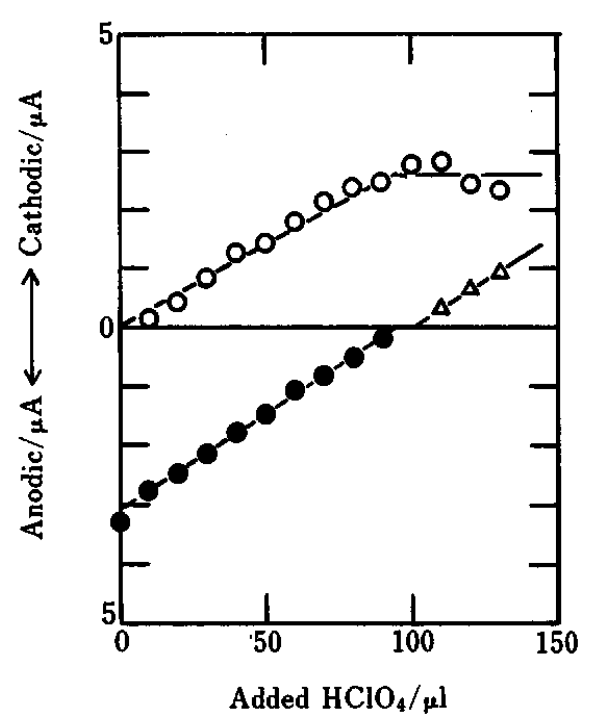

Fig. 4 Amperometric titrations of $0.50 \mathrm{mmol} \mathrm{dm}^{-3}$ cryptand[2.2] (10 ml) with $0.1 \mathrm{~mol} \mathrm{dm}^{-3} \mathrm{HClO}_{4}$ in acetonitrile. (O) Anodic wave from cryptand[2.2], (O) cathodic wave at $c a$. $-1.95 \mathrm{~V},(\triangle)$ cathodic wave of $\mathrm{HClO}_{4}$ at $c a .-1.3 \mathrm{~V}$.

to be $10^{4.3}$ and $10^{4.4}$, respectively. Formation constants similar to our values for $\mathrm{Li}^{+}, \mathrm{Na}^{+}$, and $\mathrm{K}^{+}$in acetonitrile by various techniques have been reported. ${ }^{7,17,18}$

By the way, the addition of $\mathrm{Mg}\left(\mathrm{ClO}_{4}\right)_{2}$ and $\mathrm{Sr}\left(\mathrm{ClO}_{4}\right)_{2}$ of the equivalent amount to cryptand[2.2] caused the disappearance of the anodic wave of the ligand, without forming precipitation. These phenomena were explained by the strong, but slow, interactions between cryptand[2.2] and alkaline-earth metal ions. Boss and Popov $^{19}$ have reported a $\log K$ value of $>7$ by NMR for the interaction between cryptand [2.2] and $\mathrm{Ba}^{2+}$ in $\mathrm{MeCN}$.

\section{ATCO (1,10-diaza-4,7,13,16-tetrathiacyclooctadecane)}

The strong affinity of ATCO with mercury is predicted by the displacement of all the oxygen atoms in cryptand[2.2] with sulfur atoms. The $E_{1 / 2}$ of the anodic (mercury dissolution) wave of $0.3 \mathrm{mmol} \mathrm{dm}^{-3}$ ATCO $(-0.42 \mathrm{~V})$ is much more negative than that of cryptand [2.2] $(-0.29 \mathrm{~V})$ in acetonitrile with $0.1 \mathrm{~mol} \mathrm{dm}^{-3}$ $\mathrm{Et}_{4} \mathrm{NClO}_{4}$ (or $\mathrm{Bu}_{4} \mathrm{NClO}_{4}$ ). The anodic wave of ATCO was a reversible 2-electron process (wave analysis: $30 \mathrm{mV}$ ), and was diffusion controlled $\left(i_{1} \propto \sqrt{\mathrm{h}}\right)$.

The presence of $0.1 \mathrm{~mol} \mathrm{dm}{ }^{-3} \mathrm{LiClO}_{4}$ or $\mathrm{NaClO}_{4}$ did not affect the $E_{1 / 2}$ and the height of the anodic wave ( $c f$. Table 1); this fact indicates that interactions between ATCO and the alkali metal ions are very small. Even in benzonitrile, the anodic wave of ATCO with $0.1 \mathrm{~mol}$ $\mathrm{dm}^{-3} \mathrm{Et}_{4} \mathrm{NClO}_{4}\left(E_{1 / 2}=-0.50\right)$ was not much affected by $0.1 \mathrm{~mol} \mathrm{dm}^{-3} \mathrm{Li}^{+}$or $0.05 \mathrm{~mol} \mathrm{dm}{ }^{-3} \mathrm{Na}^{+}\left(E_{1 / 2}=-0.48 \mathrm{~V}\right)$.

However, alkaline-earth metal ions showed strong interactions with ATCO in acetonitrile (Fig. 5). The presence of $0.05 \mathrm{~mol} \mathrm{dm}^{-3} \mathrm{Mg}\left(\mathrm{ClO}_{4}\right)_{2}$ or $\mathrm{Ca}\left(\mathrm{ClO}_{4}\right)_{2}$ caused the anodic wave of ATCO to disappear. With $\mathrm{Sr}\left(\mathrm{ClO}_{4}\right)_{2}$ or $\mathrm{Ba}\left(\mathrm{ClO}_{4}\right)_{2}$, on the other hand, the anodic wave of ATCO was shifted positively. The formation 


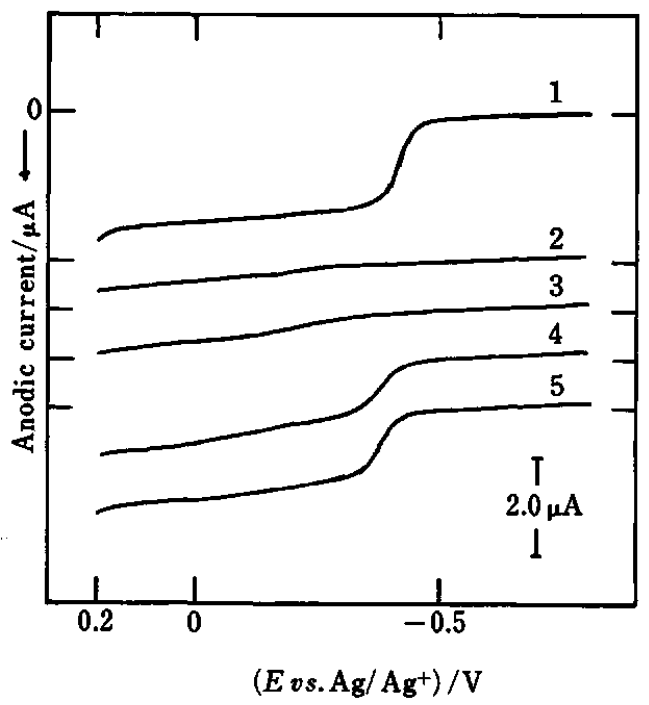

Fig. 5 D.c. polarograms of $0.30 \mathrm{mmol} \mathrm{dm}^{-3}$ ATCO in acetonitrile containing various supporting electrolytes. (1) $0.1 \mathrm{~mol} \mathrm{dm}^{-3} \mathrm{Et}_{4} \mathrm{NClO}_{4}$, (2) $0.05 \mathrm{~mol} \mathrm{dm}^{-3} \mathrm{Mg}\left(\mathrm{ClO}_{4}\right)_{2}$, (3) $0.05 \mathrm{~mol} \mathrm{dm}^{-3} \mathrm{Ca}\left(\mathrm{ClO}_{4}\right)_{2}$, (4) $0.05 \mathrm{~mol} \mathrm{dm}^{-3} \mathrm{Sr}\left(\mathrm{ClO}_{4}\right)_{2}$, (5) $0.05 \mathrm{~mol} \mathrm{dm}^{-3} \mathrm{Ba}\left(\mathrm{ClO}_{4}\right)_{2}$.

Table 3 Formation constants $\left(\log K_{p}\right)$ between cations and ATCO in acetonitrile, obtained by the anodic wave of ATCO and the cathodic wave of $\mathrm{Hg}^{2+}$-ATCO

\begin{tabular}{llllcl}
\hline \multirow{2}{*}{ Cation } & \multicolumn{2}{c}{$\begin{array}{c}\text { Anodic wave of } \\
\text { ATCO }\end{array}$} & & \multicolumn{2}{c}{$\begin{array}{c}\text { Cathodic wave of } \\
\mathrm{Hg}^{2+} \text {-ATCO }\end{array}$} \\
\cline { 2 - 3 } \cline { 5 - 6 } & $\log K_{1}$ & $\log K_{2}$ & & $\log K_{1}$ & $\log K_{2}$ \\
\hline $\mathrm{Sr}^{2+}$ & $2.5_{5}$ & & & 2.4 & \\
$\mathrm{Ba}^{2+}$ & 2.5 & & & 2.4 & \\
$\mathrm{Bu}_{3} \mathrm{NH}^{+}$ & 2.0 & 3.2 & & - & - \\
\hline
\end{tabular}

constants of $\left[\mathrm{SrL}^{\prime}\right]^{2+}$ and $\left[\mathrm{BaL}^{\prime}\right]^{2+}\left(\mathrm{L}^{\prime}=\mathrm{ATCO}\right)$ in acetonitrile were calculated using Eq. (3) to be $10^{2.55}$ and $10^{2.5}$, respectively. The slopes $\left(\Delta E_{1 / 2} / \Delta \log \left[\mathrm{M}^{2+}\right]\right)$ were $37 \mathrm{mV}$ and $31 \mathrm{mV}$ for $\mathrm{Sr}^{2+}$ and $\mathrm{Ba}^{2+}$, respectively. The decreases (to some extent) in the reversibility and the wave-height due to the presence of $\mathrm{Sr}^{2+}$ and $\mathrm{Ba}^{2+}$ were ignored. The (overall) formation constant of $\left(\mathrm{Bu}_{3}\right.$ $\left.\mathrm{NH}^{+}\right) \mathbf{L}^{\prime}$ and $\left(\mathrm{Bu}_{3} \mathrm{NH}^{+}\right)_{2} \mathbf{L}^{\prime}$ were also obtained (Table 3).

The cause for the disappearance of the anodic wave of ATCO in the presence of $\mathrm{Mg}^{2+}$ and $\mathrm{Ca}^{2+}$ was examined as follows: $0.50 \mathrm{mmol} \mathrm{dm}^{-3}$ ATCO $(10 \mathrm{ml})$ was titrated amperometrically with $0.1 \mathrm{~mol} \mathrm{dm}^{-3} \mathrm{Mg}\left(\mathrm{ClO}_{4}\right)_{2}$. Upon the addition of $\mathrm{Mg}^{2+}$, the wave-height decreased linearly up to the equivalent point $\left(50 \mu \mathrm{l},\left[\mathrm{L}^{\prime}\right]:\left[\mathrm{Mg}^{2+}\right]=1: 1\right)$. A further addition of $\mathrm{Mg}^{2+}$ did not reproduce the anodic wave. The titration curve with $\mathrm{Ca}\left(\mathrm{ClO}_{4}\right)_{2}$ (under conditions similar to the case of $\mathrm{Mg}^{2+}$ ) gave a much more gentle slope. Even 100 or $200 \mu \mathrm{l}$ of the $\mathrm{Ca}^{2+}$ solution did not decrease the wave-height very much. By a further addition, the wave-height gradually decreased, and became one-third at $2.0 \mathrm{ml}$ of the $\mathrm{Ca}^{2+}$ solution. Precipitates were not observed during the titrations.
Based on the above observation, we have concluded that disappearance of the anodic wave in the presence of sufficient amounts of $\mathrm{Mg}^{2+}$ and $\mathrm{Ca}^{2+}$ should have been caused by strong, but slow (electrochemically irreversible) interactions between ATCO and the alkalineearth cations of smaller ion sizes.

The anodic wave of ATCO at a rather negative potential indicated the strong affinity of ATCO with mercury. The formation constant of the $\left[\mathrm{HgL}^{\prime}\right]^{2+}$ complex was roughly estimated to be $\log K=22.3$ ( $c f$., $\log K=18.0$ for cryptand[2.2]) by the $\Delta E$ between $E_{1 / 2}$ of $L^{\prime}$ and the positive cut-off potential in the absence of $L^{\prime}$. The addition of an equivalent amount of $\mathrm{Hg}\left(\mathrm{ClO}_{4}\right)_{2}$ to an ATCO-MeCN solution readily gave the $\left[\mathrm{HgL}^{\prime}\right]^{2+}$ complex, as was the case for cryptand[2.2]. The cathodic wave of $\left[\mathrm{HgL}^{\prime}\right]^{2+}$ was utilized to obtain the formation constants of $\left[\mathrm{SrL}^{\prime}\right]^{2+}$ and $\left[\mathrm{BaL}^{\prime}\right]^{2+}(c f$. Table 3). The smaller solubility of ATCO in MeCN prevented us from utilizing the usual method to obtain the formation constants of the complexes.

An amperometric titration of $\mathrm{ATCO}$ with $\mathrm{HClO}_{4}$ in acetonitrile gave results similar to those of cryptand[2.2] (cf. Fig. 4), except that a small second anodic-wave at $-0.16 \mathrm{~V}$ was observed in addition to the original anodic wave at $-0.42 \mathrm{~V}$. The small second anodic-wave might have been caused by an interaction between mercury and the monoprotonated ATCO species, i.e., $\mathrm{L}^{\prime} \mathrm{H}^{+}$. We have observed ${ }^{6}$ a very clear second anodic-wave upon the addition of $\mathrm{HClO}_{4}$ to tetramethylcyclam (TMC) in the same solvent, and attributed it to an interaction between mercury and monoprotonated TMC.

\section{References}

1. M. Hojo and Y. Imai, Bull. Chem. Soc. Jpn., 56, 1963 (1983).

2. M. Hojo, A. Tanio, Y. Miyauchi and Y. Imai, Chem. Lett., $1991,1827$.

3. Y. Miyauchi, M. Hojo, H. Moriyama and Y. Imai, $J$. Chem. Soc., Faraday Trans., 88, 3175 (1992).

4. M. Hojo and Y. Imai, J. Electroanal. Chem., 209, 297 (1986).

5. M. Hojo and Y. Imai, Anal. Sci, 1, 185 (1985).

6. M. Hojo, M. Hagiwara, H. Nagai and Y. Imai, J. Electroanal. Chem. Interfacial Electrochem., 234, 251 (1987).

7. R. M. Izatt, K. Pawlak, J. S. Bradshaw and R. L. Bruening, Chem. Rev., 91, 1721 (1991).

8. R. M. Izatt, J. S. Bradshaw, K. Rawlak, R. L. Bruening and B. J. Tarbet, Chem. Rev., 92, 1261 (1992).

9. H.-J. Buschmann, E. Cleve and E. Schollmeyer, $J$. Solution Chem., 23, 569 (1994).

10. K. Chayama, K. Hara, Y. Tamarai, H. Tsuji, Y. Kusaka, Y. Hori and E. Sekido, Proc. Int. Con. Solvent Extraction, 1993, 585.

11. K. Chayama, N. Awano, Y. Tamari, H. Tsuji and E. Sekido, Bunseki Kagaku, 42, 687 (1993).

12. B. Dietrich, J. M. Lehn and J. P. Sauvage, J. Chem. Soc., Chem. Commun., 1970, 1055.

13. M. Hojo and Y. Imai, Anal. Chem., 57, 509 (1985).

14. V. Gutmann, "The Donor-Acceptor Approach to Molecular 
Interactions", Chap. 2, Plenum, New York, 1978.

15. M. Y. Suh, T. Y. Eom and S. J. Kim., Bull. Korean Chem. Soc., 4, 231 (1983).

16. M. Hojo and Y. Imai, Anal. Sci., 2, 21 (1986).

17. A. A.-Hamdan and S. F. Lincoln, Inorg. Chem., 30, 462 (1991).
18. P. Firman, L. J. Rodriguez, S. Petrucci and E. M. Eyring, J. Phys. Chem., 96, 2376 (1992).

19. R. D. Boss and A. I. Popov, Inorg. Chem., 25, 1747 (1986).

(Received September 2, 1994) (Accepted February 24, 1995) 